\title{
Does Terms of Trade Matter for Economic Growth? A Focus on Natural Resource- Rich Sub-Saharan African Countries
}

\author{
Nzeh Innocent Chile ${ }^{1 \star}$ \\ Benedict I. Uzoechina ${ }^{2}$ \\ Millicent Adanne Eze ${ }^{3}$ \\ Chika P. Imoagwu' (D) \\ Ozoh Joan Nwamaka ${ }^{5}$
}

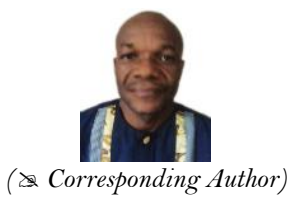

Department of Economics, Renaissance University, Ugbawka, Enugu State, Nigeria. 'Email: nzechile@yahoo.com Tel: +234-8034222084.

${ }^{2}$ Department of Economics, Nnamdi Azikiwe University, Awka, Anambra State, Nigeria.

'Email: ib.uzoechina@unizik.edu.ng Tel:+234-8063304867

${ }^{3}$ School of Business and Social Sciences, Abertay University, Dundee, United Kingdom.

${ }^{s}$ Email:ezemillicent@gmail.com Tel: (+44)7459452103

${ }_{4,5}^{45}$ Department of Economics, Nnamdi Azikiwe University, Awka, Anambra State, Nigeria.

"Email: cp.imoagrwu@unizik.edu.ng Tel:+234-8035774516

Email:jn.ozoh@unizik.edu.ng Tel: +234-8066678226

\section{Abstract}

The contention that deteriorating terms of trade exists in countries that rely heavily on the exploitation and export of natural resources motivated us in this study. We therefore sought to investigate the impact of terms of trade on economic growth in natural resource-rich sub-Saharan African countries. We carried out the study using annual series that span a period of 1990-2019 under the framework of panel Random and Fixed effects. Our findings indicate that a long run relationship exists between GDP and the explanatory variables used in the study. Results also show that, while cross-section random effects indicates that terms of trade positively impacts on GDP, period fixed effects shows that terms of trade negatively impacts on GDP even though it is not significant. Results of our study also show that in all the models, labour force total and FDI have positive impact on GDP, while trade openness impacts on GDP negatively. We therefore recommend that the SSA natural resource-rich countries should diversify their economies away from the traditional natural resources base. Also human capital should be improved through sound education and training, while all the bottlenecks that constrain the inflow of foreign direct investment should be dismantled.

Keywords: Natural resources, GDP, Random effects, Fixed effects, Terms of trade, Labour force, FDI.

JEL Classification: N57; O40; C33; F10; J21; F21.

Citation | Nzeh Innocent Chile; Benedict I. Uzoechina; Millicent Adanne Eze; Chika P. Imoagwu; Ozoh Joan Nwamaka (2021). Does Terms of Trade Matter for Economic Growth? A Focus on Natural Resource-Rich Sub-Saharan African Countries. Economy, 8(2): 2634 .

History:

Received: 15 September 202

Revised: 18 October 2021

Accepted: 12 October 2021

Published: 8 December 2021

Licensed: This work is licensed under a Creative Commons

Attribution 3.0 License (cc) EY

Publisher: Asian Online Journal Publishing Group
Acknowledgement: All authors contributed to the conception and design of the study.

Funding: This study received no specific financial support.

Competing Interests: The authors declare that they have no conflict of interests.

Transparency: The authors confirm that the manuscript is an honest, accurate, and transparent account of the study was reported; that no vital features of the study have been omitted; and that any discrepancies from the study as planned have been explained.

Ethical: This study follows all ethical practices during writing.

\section{Contents}

1. Background to the Study.

2. Theoretical Issues Relating to Terms of Trade ........ 29

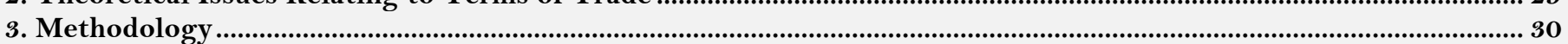

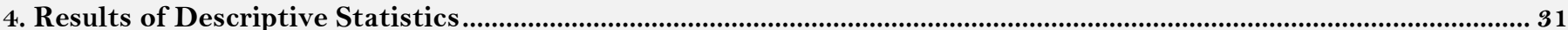

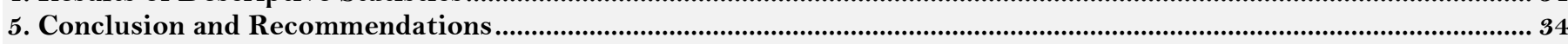

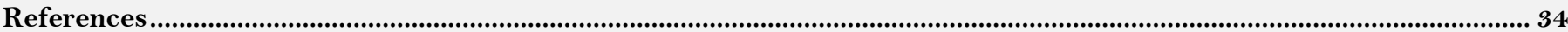




\section{Contribution of this paper to the literature}

This study contributes to the existing literature by focusing on the link between terms of trade and economic growth in natural resource-rich sub-Saharan African countries.

\section{Background to the Study}

The contribution of international trade on economic growth has been emphasized since the days of classical economists such as Adam Smith and David Ricardo. By offering opportunities for countries to export their products to other countries, international trade enables countries to earn income that is used to facilitate further, the development of the domestic economy. The growth effect of international trade is evaluated from, among other factors, the terms of trade condition facing the export price of countries and some studies have pointed to a positive link between economic growth and terms of trade. For instance, terms of trade improvement has been found to encourage higher levels of investment, thus rapid economic growth (Mendoza, 1997). In corroborating this stance, Easterly, Kremer, Pritchett, and Summers (1993) find that variability in terms of trade are highly correlated with growth and this conforms to findings of studies by Barro and Sala-i-Martin (1995) and Fischer (1993).

Through international trade, countries can specialize in the production and export of products that they have comparative advantage. Notwithstanding the gains inherent with specialization, it comes with its own drawback. This limitation puts a constraint on the developing countries whose trade relation with developed countries is usually lopsided. As noted in separate studies by Prebisch and Singer, developed countries specialize in the production and exports of manufactured products and services that have low substitutes and enjoy stable prices. On the other hand, developing countries, with their weak industrial base, specialize in production and exports of primary commodities that are highly competitive and which experience volatility in prices. Deterioration in terms of trade is therefore among the determinants of widening income gap between developing countries and developed countries. Sachs and Warner (2001) observed that specialization in the production and export of primary products is a major determinant of economic outcome

Our study is focused on natural resource-rich sub-Saharan African (SSA) countries which fall under the developing countries hypothesized to be likely faced with deteriorating terms of trade. We are motivated by the fact that rich natural resource endowments have been found to induce countries endowed with them to abandon their critical sectors by failing to diversify their economies and this tendency ends up depressing their GDP. Natural resources abundant countries usually face resource-curse and Dutch disease syndrome as they are rigidly stuck to the exploitation and exportation of the abundant natural resources. A study by Carmignani and Chowdhury (2007) has shown that undue dependence on the export of primary commodities negatively affect economic growth in SSA. Irrespective of the fact that a preponderance of studies have been done on the link between terms of trade and economic growth, in literature; there is an absence of studies of such in the context of natural resource-rich sub-Saharan African countries. Our paper thus aims to fill this gap in literature by investigating the nexus between terms of trade and economic growth in SSA countries.

\subsection{Stylized Facts on Sub-Saharan African Countries}

By virtue of their huge natural resource deposits, the SSA countries usually export their commodities unprocessed. Several theoretical views have been raised concerning the deteriorating export price of commodities in relation to industrialized goods. Figure 1 below shows that Congo Democratic Republic and Mauritania are the two countries with the highest receipt of natural resources rent respectively and this is followed by Nigeria. South Africa and Botswana are the least recipient of natural resources rent within the study period. In 2003, 2009 and 2011 through 2019 Congo Democratic Republic was on top of other countries in her receipt of natural resources rent and in 2008 and 2010, Mauritania got the highest rent. With respect to terms of trade, evidence from Figure 2 below shows that Nigeria has the highest terms of trade (proxied by net barter term of trade) and this is followed by Mauritania and South Africa respectively. It should be noted that the highest recipient of natural resources rent are hardly the countries with the highest terms of trade. A case in point here is Congo Democratic Republic which has a high natural resources rent but has a very low terms of trade. Worthy of note also is the fact that Nigeria and South Africa which are the most industrialized countries among the group are rarely the highest natural resources rent recipients but their terms of trade is high. The implication of this development is that commodity terms of trade in counties with huge natural resources rent deteriorates compared to countries with a relative industrial development. The fact that Nigeria has the highest terms of trade within the sample period could be because of export from her huge deposit of oil couple with her relative high industrial base.

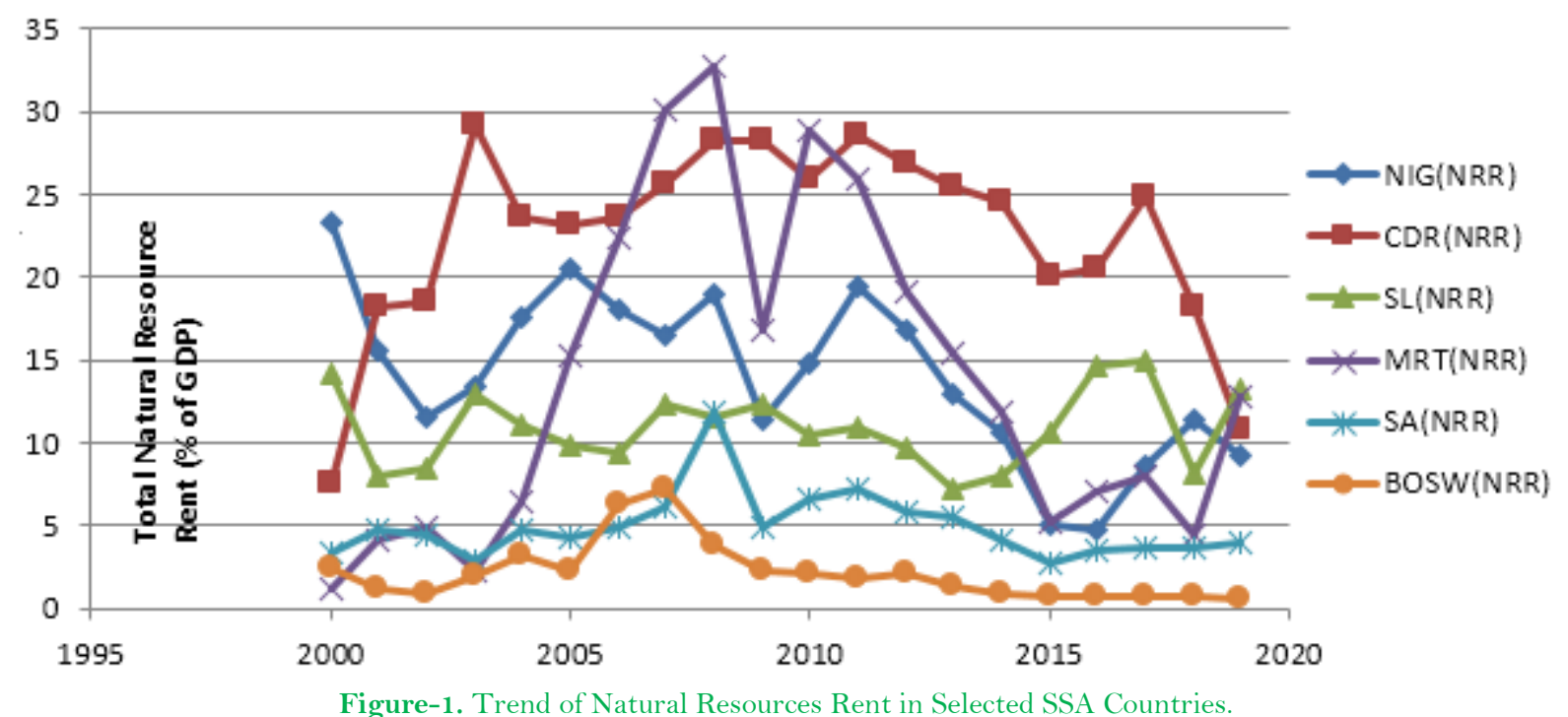




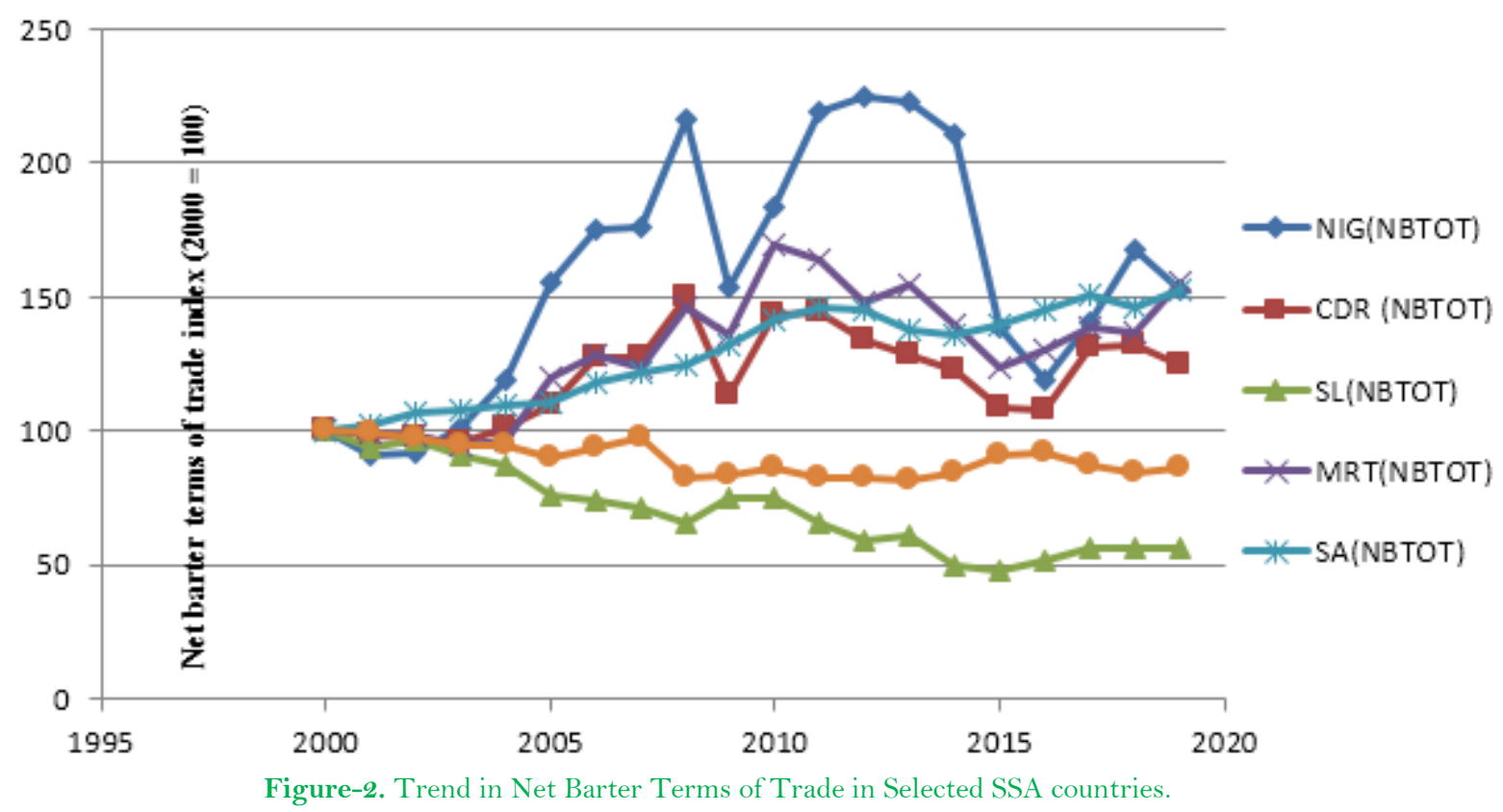

In terms of export share to GDP, Figure 3 below shows that in all the years, Botswana's export share to GDP is the highest and this is followed by Mauritania and Congo Democratic Republic, respectively. Figure 2 above shows that Botswana, even with her high share of export to GDP, is among the countries with the least terms of trade. This implies that her terms of trade deteriorates vis-à-vis her trading partners. We also noticed that the two countries in the group with the highest GDP, namely: Nigeria and South Africa have a lower export to GDP. With a relatively high concentration of business activities in these two countries, the proportion of export to GDP is expectedly low as many domestic business activities not meant for export contribute to GDP. For instance, around 2014, Nigeria rebased her economy by incorporating the contribution of some sectors such as the telecommunication that were hitherto not included in her GDP. Consequently, the country's GDP expanded and became the highest in Africa with the period.

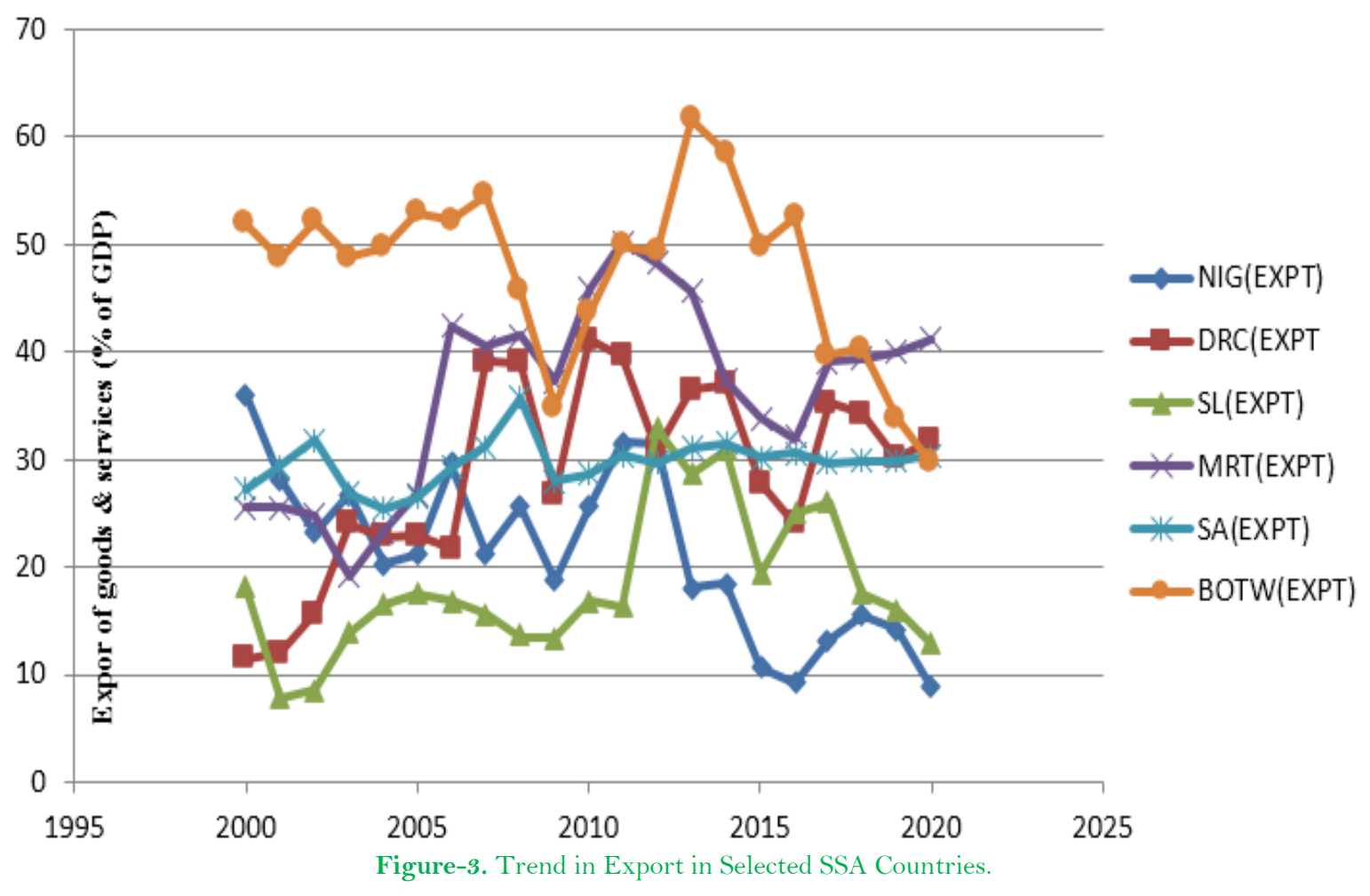

With respect to the share of import to GDP, Figure 4 below shows that in 2005 through 2008, Mauritania's import as a percentage of GDP is highest compared to other countries in the sample. In 2009 and 2010 as well as 2012 through 2015 Botswana's share of import to GDP was highest. Evidence in Figure 2 above shows that Botswana's term of trade is very low and this is owing to her high import share of GDP. Sierra Leone's share of import to GDP was the highest between 2011 and 2016. In a similar vein, the import share of Sierra Leone to her GDP accounts for her low terms of trade within the sample period. We noticed that Nigeria and South Africa which are the two countries with the biggest GDP has the least share of import as a percentage of GDP. This shows that import in these countries take only a smaller portion of their relatively huge GDP. 


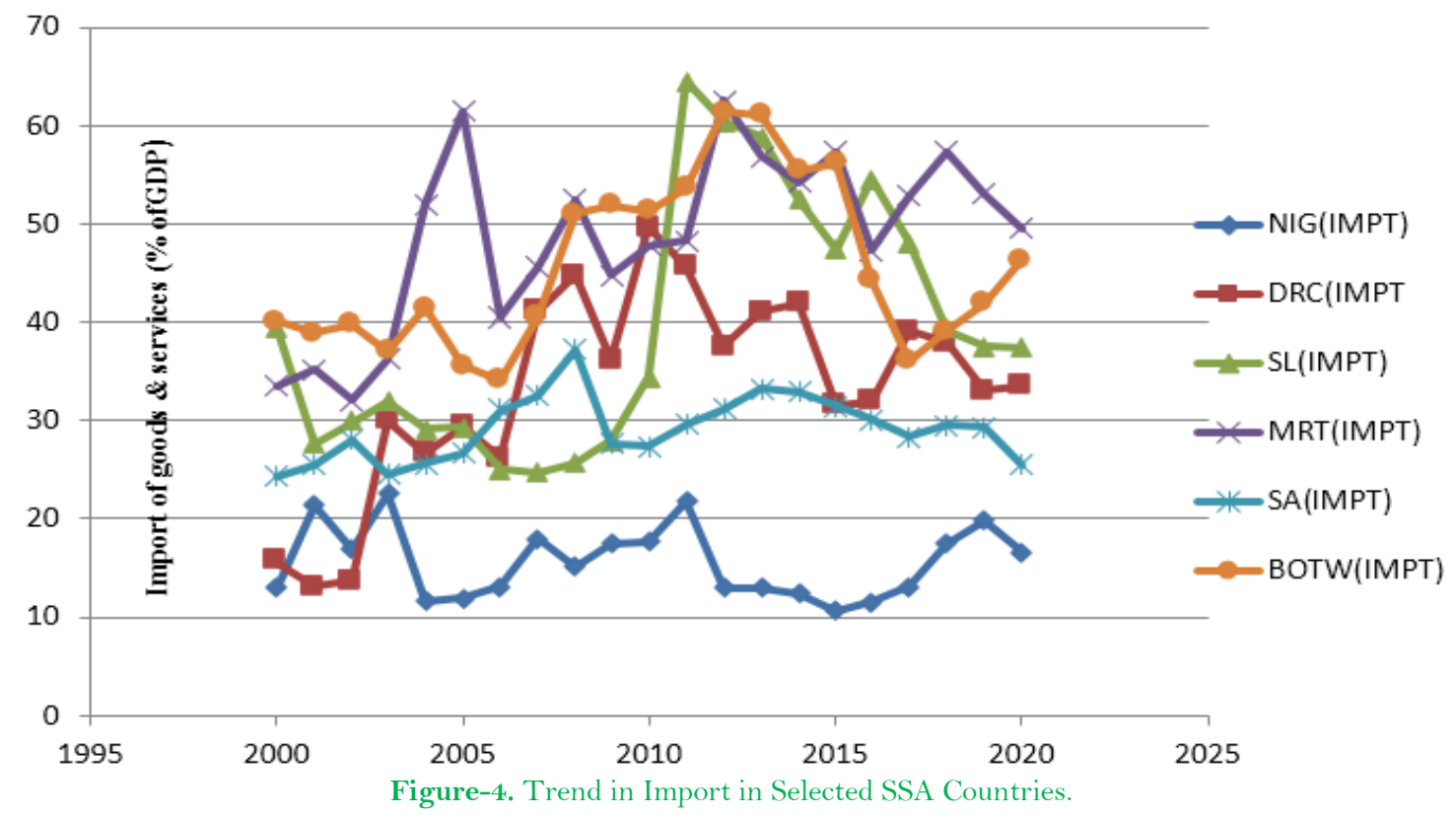

\section{Theoretical Issues Relating to Terms of Trade}

Over the years, several theories have been developed to help explain the relationship between countries' terms of trade and their economic performance. In 1950, Raoul Prebisch and Hans Singer raised a popular argument that developing countries which exported primary products and imported manufactured products had experienced both a decline in their terms of trade and depressing incomes. Specifically, Prebisch raised the concern over trade relationship between developed and developing countries by observing that since developing countries export more of primary products that are less competitive at the international market, the commodity terms of trade usually deteriorates in relation to industrialized goods. With a low-income elasticity of demand for primary commodities, Prebisch observed that the demand for goods of this kind does not keep pace with income. By implication, developing countries tend to compete more intensely with each other for markets for their commodities. They go about this through reduction in prices; which ultimately affect their terms of trade with developed countries. If a country's terms of trade continues to deteriorate, it implies that this country will experience a decline in the purchasing power of these exports vis-à-vis the value of goods and services imported from abroad. This viewpoint is in sync with the observation by Hans Singer in a separate study, thus this is referred to in the literature as the Prebisch-Singer thesis.

In another direction, Thirlwall (1979) provided an explanation for why the trade balance is linked to economic growth. Thirlwall model was used to explain the export performance and import behavior in determining the longterm economic growth. It observed that by increasing foreign exchange revenue generated through export sale of commodities, such provides avenue to sustainably finance increasing imports arising from increased domestic economic activity. Bruno and Sachs (1985) also provided explanation for the nexus between commodity prices and economic activity. Two channels were identified by Bruno and Sachs (1985) through which commodity prices can influence output. The first is that changes in commodity prices will shift the factor price frontier and the second is that commodity prices affect demand through real wages, employment and the world distribution of wealth.

\subsection{Empirical Literature}

Over the years, there has been wide interest in the study that investigates the nexus between terms of trade and economic growth. It is noteworthy however, that there has never been a uniform outcome of the appropriate link between the two as while some studies show a negative link, some indicate that terms of trade is positively related to GDP.

Using time series data from 1990-2008, Fatima (2010) examined terms of trade behavior in Pakistan. The paper finds that unfavourable terms of trade has a negative impact on economic growth of Pakistan, as it ultimately reduces gross domestic product. In a study involving 94 developed and developing countries over a period of 20042008, Jawaid and Waheed (2011) showed that terms of trade has a significant and positive effect on economic growth. In India, Jawaid. and Raza (2012) using annual series spanning a period of 1980-2010, found a significant and positive long run relationship between terms of trade and economic growth. The study also found that the volatility of terms of trade has negative and significant effect on economic growth. In another cross-country study involving sub-Saharan African countries, Mputu (2016) investigated the nexus between terms of trade, trade openness and economic growth. Under the framework of Fixed and Random effects models and over a period of 1980-2011, finding show that terms of trade has a positive relationship with GDP level in SSA countries

In a study for China, Jebran, Iqbal, Bhat, and Ali (2018) using the framework of ARDL over a period of 19802013, revealed that terms of trade significantly and adversely affects economic growth in the short run as well as in the long run. The Granger causality results revealed a unidirectional causality running from terms of trade to labor force. Another study for Pakistan by Jebran et al. (2018) using the ARDL and over a period of 1980-2013, showed a significant negative long-run and short-run effects of terms of trade on economic growth. This finding finds support in Fatima (2010). Dabas and Delbianco (2019) investigates the effects of the ratio of exports/GDP and the terms of trade on growth among countries with different level of development and openness and found that terms of trade is not favourable to the growth prospects of poor countries. In a cross-country study involving developing countries, Jawaid.., Waheed, and Siddiqui (2020) showed a mixed result. While in some countries, terms of trade has a positive impact on GDP, in others the impact is negative. Another cross-country study involving some 
countries in the European Union by Blavasciunaite, Garsviene, and Matuzeviciute (2020) indicated that deterioration of trade balance reduces average economic growth.

\section{Methodology}

In this study, we estimated the relationship between GDP and the regressors under the framework of the panel data models. Panel data model allows a control for variables that cannot be observed or measured such as fiscal or exchange rate policies that change over time but not across entities like countries. The model uses subscript $\mathrm{i}$ to denote individual entities while $t$ refers to time periods. For example, in a panel data model with $Y_{\text {it }}$ as the dependent variable, this is denoted as $\mathrm{i} \ldots . .1, \ldots, \mathrm{N}$ across all time periods $\mathrm{t}=1, \ldots, \mathrm{T}$. The primary difference between panel data models and time series models is that panel data models allow for heterogeneity across groups and introduce individual-specific effects. We explored three different models in this study, namely: the pooled OLS, fixed effects and random effects by comparing the estimated results of their parameters. The pooled OLS can be explained below in Equation 1 as follows:

$$
y_{i t}=\beta x_{i t}+\alpha+\varepsilon_{i t}
$$

In Equation 1 above, $\mathrm{x}$ represents the observable characteristics such as income level and $\beta$ is the coefficient of the observable parameter, while $\alpha$ and $\varepsilon_{i t}$ are the intercept term and error term respectively. Under the pooled OLS, there are no unobservable individual-specific effects as the intercept captures a uniform effect for all the entities. The panel data can thus be treated as one large, pooled dataset. The implication is that, if we proceed to estimate $\beta$ without accounting for heterogeneity within individual groups, the estimator will be inconsistent and biased.

As a departure from the pooled OLS, the fixed effects model introduces heterogeneity by assuming that individual-specific factors may impact or bias the independent variables and as such there is need to control them. The assumption is that correlation exists between individual entity's error term and the independent variables. Fixed effects remove the effect of such time-invariant characteristics in a way that it enables one to investigate the net effect of the explanatory variables on the dependent variable. Fixed effects model also assumes that those timeinvariant features are unique to the individual entity and should not be correlated with other individual characteristics. Each individual entity is unique; hence an error term belonging to any entity as well as the constant that captures individual characteristics should not be correlated with the others. If such should occur, the fixed effect model is not suitable because any inference drawn with the outcome of its result may be misleading. The fixed effect model is specified in Equation 2 below as follows:

$$
Y_{i t}=\beta_{1} X_{i t}+\alpha_{i}+\mu_{i t}
$$

where

$\alpha_{i}(i=1 \ldots n)$ is the unknown intercept for each entity ( $n$ entity-specific intercepts), $Y_{i t}$ is the dependent variable $(i$ $=$ entity and $t=$ time), $X_{i t}$ represents the explanatory variables for each entity at $t, \beta_{1}$ is the coefficient of the explanatory variables, $\mu_{i t}$ represents the error term

Failure to use the fixed effects model, the alternative model should be random effects model. A major distinguishing factor behind random effects model is that, unlike the fixed effects model, the changes across individual entities is assumed to be random and uncorrelated with the independent variables included in the model. The assumption under the random effects that the individual entity's error term is not correlated with the regressors means that time-invariant variables such as fiscal or monetary policies are allowed to play a role as explanatory variables. In the fixed effects model these time-invariant variables are absorbed by the intercept.

With random effect model, one can generalize the inferences beyond the sample used in the model, however; the problem with this model is that some variables may not be available such that it may lead to omitted variable bias in the model. The random effects model is specified in Equation 3 below as follows:

$$
Y_{i t}=\beta_{1} X_{i t}+\alpha+\mu_{i t}+\varepsilon_{i t}
$$

where $\mu_{i t}$ is between entity error term and $\varepsilon_{i t}$ is within entity error term

Beyond specifying the model linking economic growth and terms of trade, we considered other variables such as trade openness, capital and labour which are equally important determinants of economic growth. Our model specification is a panel data model modified from Mputu (2016) and Equation 4 below captures the model

$$
G D P_{i t}=\lambda_{0}+\lambda_{1} N B T O T_{i t}+\lambda_{2} F D I_{i t}+\lambda_{3} G F C F_{i t}+\lambda_{4} L F T_{i t}+\lambda_{5} T O P E N_{i t}+\mu_{i t}+\varepsilon_{i t}
$$

Where

$G D P_{i t}=$ Gross Domestic Product (A proxy for economic growth) in year $\mathrm{t}$ for country i.

$\lambda_{O}=$ Intercept term

$N B T O T_{i t}=$ Net barter terms of trade ( A proxy for terms of trade) in year t for country i.

$F D I_{i t}=$ Foreign direct investment in year $\mathrm{t}$ for country $\mathrm{i}$.

$G F C F_{i t}=$ Gross fixed capital formation in year $\mathrm{t}$ for country $\mathrm{i}$.

$L F T_{i t}=$ Labour force total in year $\mathrm{t}$ for country $\mathrm{i}$.

$T O P E N_{i t}=$ Trade openness in year $\mathrm{t}$ for country $\mathrm{i}$.

$\mu_{i t}=$ between entity error term.

$\varepsilon_{i t}=$ within entity error term. 


\subsection{Data and Sources}

We used annual dataset in this study covering a period of 1990-2019 and the time period considered is informed by data availability of some of the variables included in the study. All the data were sourced from the World Bank's World Development Index data bank. The countries selected in our study were informed by the grouping done by the Economic Commission for Africa in her 2011 report that grouped sub-Saharan African countries on the basis of resource-rich, resource-poor and landlocked countries. The countries that fall under resource-rich which we included in our study are: Nigeria, South Africa, Botswana, Congo Democratic Republic, Sierra Leone and Mauritania. We used GDP at constant 2010 US $\$$ to proxy economic growth. Following Mputu (2016) we used Net barter terms of trade index $(2000=100)$ as an indicator for terms of trade. Net inflows at current US\$ was used to represent foreign direct investment. Gross fixed capital formation (\% of GDP) was used to represent gross fixed capital formation and trade openness was calculated as the ratio of the sum of export and import. We logged GDP and FDI in excel package before including them in the estimation.

\section{Results of Descriptive Statistics}

Table 1 below displays the results of descriptive statistics of the variables used in the study. Evidence from the results indicate that the mean value of GDP, Net barter terms of trade, Gross fixed capital formation, Labour force total, Foreign direct investment and Trade openness are: 10.41935, 104.6052, 23.09278, 6.742246, 8.486756 and 11.64456, respectively. The variable with the highest mean is Net barter terms of trade with a standard deviation of 41.44478. On the other hand the variable with the lowest mean value is Labour force total with a standard deviation of 0.727383 .In terms of the range, the variable that exhibited the highest range is Net barter terms of trade, indicating that the variable experiences volatility within the study period. The test of skewness shows that all the variables we applied in the study are skewed to the right, while they also exhibited platykurtic in their kurtosis. The Jarque Bera statistics show that with probability values of the variable which are less than 5 percent, the series are normally distributed.

\begin{tabular}{l|c|c|c|c|c|c}
\hline & GDP & TBTOTle-1. Descriptive Statistics. & LFT & FDI & TOPEN \\
\hline Mean & 10.41935 & 104.6052 & 23.09278 & 6.742246 & 8.486756 & 11.64456 \\
\hline Median & 10.21180 & 100.0000 & 21.31350 & 7.130176 & 8.622676 & 11.82139 \\
\hline Maximum & 11.67867 & 224.6432 & 93.54746 & 7.800901 & 9.994977 & 13.22011 \\
\hline Minimum & 9.113214 & 0.000000 & 0.000000 & 5.632815 & 5.020713 & 9.545307 \\
\hline Std. Dev. & 0.848263 & 41.44478 & 12.89481 & 0.727383 & 1.000305 & 1.003765 \\
\hline Skewness & 0.193410 & 0.080522 & 1.061048 & -0.057413 & -0.942510 & -0.382608 \\
\hline Kurtosis & 1.546182 & 4.282272 & 7.097017 & 1.307929 & 3.911547 & 1.966956 \\
\hline Jarque-Bera & 15.27671 & 11.27355 & 143.6997 & 19.41495 & 29.59348 & 11.15598 \\
\hline Probability & 0.000482 & 0.003564 & 0.000000 & 0.000061 & 0.000000 & 0.003780 \\
\hline Sum & 1687.935 & 16946.04 & 3741.030 & 1092.244 & 1374.855 & 1886.419 \\
\hline Sum Sq. Dev. & 115.8477 & 276544.9 & 26770.45 & 85.18280 & 161.0982 & 162.2147 \\
\hline Observations & 162 & 162 & 162 & 162 & 162 & 162 \\
\hline
\end{tabular}

\subsection{Results of Panel Unit Roots}

In order to confirm the stationarity of the series used in the study so as to avoid the problem of the results being spurious, the panel unit root tests we conducted are presented in Table 1 and 2 below. To carry out the tests, we utilized the Levin, Lin \& Chu (LLC), Im, Pesaran and Shin (IPS), Augment Dickey Fuller-Fisher (ADF-Fisher) and Phillp-Perron-Fisher (PP-Fisher) tests in this study. We decomposed the test into two sections. One section comprised of IPS, ADF-Fisher and PP-Fisher deals with the null hypothesis of the existence of unit root for individual countries and the other section, comprising LLC deals with the existence of unit root for all the countries pooled together. In Table 2, the results at level indicate that Gross fixed capital formation, Foreign direct investment and Trade openness achieved stationairy at level, $i e, \mathrm{I}(0)$ under the LLC. Also, under IPS and ADFFisher, Gross fixed capital formation and Foreign direct investment attained stationarity at level. Lastly, under the PP-Fisher, Gross fixed capital formation and Trade openness achieved stationarity at level. The results so far indicate that we cannot continue the analysis based on the outcome of unit root test at level. This is because we cannot reject the null hypothesis of no unit root on all the variables.

\begin{tabular}{c|c|c|c|c}
\multicolumn{5}{c}{ Table-2. Result of Panel Unit Root at Level. } \\
\hline & Common Unit Root & \multicolumn{3}{|c}{ Individual Unit Root } \\
\hline Series & LLC & IPS & ADF-Fisher & PP-Fisher \\
\hline GDP & $1.65685(0.9512)$ & $4.80080(1.0000)$ & $0.69790(1.0000)$ & $0.16116(1.0000)$ \\
\hline NBTOT & $0.56658(0.7145)$ & $0.84922(0.8021)$ & $6.88317(0.8652)$ & $8.56876(0.7393)$ \\
\hline GFCF & $-2.11267(0.0173)^{*}$ & $-2.20526(0.0137)^{*}$ & $22.7924(0.0295)^{*}$ & $35.0049(0.0005)^{*}$ \\
\hline LFT & $1.50505(0.9338)$ & $3.91597(1.0000)$ & $1.44229(0.9999)$ & $3.95019(0.9843)$ \\
\hline FDI & $-3.24064(0.0006)^{*}$ & $-2.01848(0.0218)^{*}$ & $23.1447(0.0265)^{*}$ & $17.7510(0.1235)$ \\
\hline TOPEN & $-1.94754(0.0257)^{*}$ & $1.22607(0.889)$ & $6.30656(0.8998)$ & $18.8968(0.0910)^{*} *$ \\
\hline Note: * and ** signify significant levels at both the $5 \%$ and 10\% respectively.
\end{tabular}

Since not all the series achieved stationarity at level, we proceeded to investigate their stationarity at first difference as shown in Table 3 below. From the results, only labour force total did not achieve stationarity under LLC, while other series became stationary at the 5 percent level. Under the IPS, ADF-Fisher and PP-Fisher, all the series achieved stationarity at the 5 percent level. Therefore, after first difference, all the series we employed in the study became $\mathrm{I}(1)$. 
Table-3. Result of panel unit root at first difference

\begin{tabular}{c|c|c|c|c}
\hline & Common Unit Root & \multicolumn{3}{|c}{ Individual Unit Root } \\
\hline & LLC & IPS & ADF Fisher & PP-Fisher \\
\hline$\Delta$ GDP & $-3.72235(0.0001)^{*}$ & $-4.68957(0.0000)^{*}$ & $45.6192(0.0000)^{*}$ & $57.0196(0.0000)^{*}$ \\
\hline$\Delta$ NBTOT & $-5.00232(0.0000)^{*}$ & $-6.55118(0.0000)^{*}$ & $63.6629(0.0000)^{*}$ & $111.065(0.0000)^{*}$ \\
\hline$\Delta$ GFCF & $-6.92952(0.0000)^{*}$ & $-7.65763(0.0000)^{*}$ & $76.5362(0.0000)^{*}$ & $104.383(0.0000)^{*}$ \\
\hline$\Delta$ LFT & $-1.23676(0.1081)$ & $-2.56349(0.0052)^{*}$ & $27.1787(0.0073)^{*}$ & $49.0163(0.0000)^{*}$ \\
\hline$\Delta$ FDI & $-4.67977(0.0000)^{*}$ & $-7.08865(0.0000)^{*}$ & $69.4274(0.0000)^{*}$ & $189.935(0.0000)^{*}$ \\
\hline$\Delta$ TOPEN & $-7.02833(0.0000)^{*}$ & $-6.09969(0.0000)^{*}$ & $59.0359(0.0000)^{*}$ & $87.9075(0.0000)^{*}$ \\
\hline Note: * and ** signify significant levels at both the 5\% and 10\% respectively.
\end{tabular}

\subsection{Panel Co-Integration Test}

Having confirmed that the series do not have unit root, we went ahead to conduct a co-integration test to ascertain whether there is a long-run association or equilibrium among the series. We employed the Kao cointegration test to achieve this. The Kao test is based on the test of significant of the residual under the null hypothesis of no co-integration. From the result in Table 4, the coefficient of the residual is -0.107656 with a tstatistic of -2.680084 and p-value of 0.0083 which is lower than 5 percent. Consequently, we cannot accept the null hypothesis, thus meaning that a long-run equilibrium exists among the variables.

Table-4. Kao Co-integration Result.

\begin{tabular}{|c|c|c|c|c|}
\hline \multicolumn{5}{|c|}{$\begin{array}{l}\text { Kao Residual Co-integration Test } \\
\text { Series: GDP NBTOT FDI GFCF LFT TOPEN } \\
\text { Dependent Variable: D(RESID) } \\
\text { Sample: } 19902019 \\
\text { Null Hypothesis: No co-integration }\end{array}$} \\
\hline Variable & Coefficient & Std. Error & t-Statistic & Prob. \\
\hline $\operatorname{RESID}(-1)$ & -0.107656 & 0.040169 & -2.680084 & 0.0083 \\
\hline
\end{tabular}

\subsection{Results of Panel Models}

With the result showing that the series are co-integrated, we present and discuss the estimated results of the coefficients of the parameters in all the models. We decided to estimate a pooled Ordinary Least Square (OLS) which we present for comparison sake. Next we present the panel fixed and random effects results. However, before that, we have to decide on which panel estimation technique is preferable. That is, between random and fixed effects techniques which one is more appropriate? To evaluate this, we employed the Hausman's chi-square statistic. The Hausman test is conducted under the assumption that the random effect is being uncorrelated with the explanatory variables. Under the null hypothesis that the error term does not have any correlation with the explanatory variables, the random effect is more appropriate if it passes this test. As a guide to this test, we tested for both the period random effect and the cross-section random effect. These tests are displayed in Table 5 below and the results show that under the cross-section test, random effect is more appropriate as we cannot reject the null hypothesis of the error terms not being correlated with the explanatory variables. However, at the 5 percent level and under the period effect, fixed effect technique is more appropriate since we have every reason to reject the null hypothesis. Thus, we can estimate a cross-section random effect model to obtain the parameter estimates.

Table-5. The Hausman Test.

\begin{tabular}{l|c|c|c}
\hline Hausman Test for Cross-Section Random Effect \\
\hline Test Summary & Chi-Sq. Statistic & Chi-Sq. d.f & Prob \\
\hline Cross-section random & 5.210925 & 5 & 0.3907 \\
\hline Hausman Test for Period Random Effect & Chi-Sq. Statistic & Chi-Sq. d.f & Prob \\
\hline Test Summary & 9.840208 & 5 & 0.0799 \\
\hline Period random &
\end{tabular}

Since the result of the Hausman test for period random effect indicates that we cannot accept the null hypothesis, we have to consider estimating a fixed effect model. However, in order to apply the appropriate model under the fixed effect, we have to conduct a joint significance test of the fixed effects estimates in least squares specifications. This test is based on the null hypothesis that there is no presence of cross-section fixed and period fixed effects. If the chi-square is significant, we reject the null hypothesis that the effects are redundant. From the result in Table 6 below, we cannot reject the hypothesis of non-existence of period effect as the p-value of the estimate is 0.9731 which is higher than the 5 percent level. Consequently, we are going to estimate period fixed effects in order to obtain the parameter estimates.

Table-6. Fixed Effect Tests

\begin{tabular}{l|c|c|c}
\hline Cross-section Fixed Effects Test \\
\hline Effects Test & Statistic & d.f. & Prob. \\
\hline Cross-section F & 836.145048 & $(5,151)$ & 0.0000 \\
\hline Cross-section Chi-square & 543.743498 & 5 & 0.0000 \\
\hline Period fixed Effects & Statistic & d.f. & Prob. \\
\hline Effects Test & 0.460889 & $(29,127)$ & 0.9913 \\
\hline Period F & 16.210469 & 29 & 0.9731 \\
\hline Period Chi-square &
\end{tabular}

The results presented in Table 7 below show that under the pooled OLS, net barter terms of trade negatively and significantly influences GDP. We also find that gross fixed capital formation, labour force total and foreign direct investment are all positively related to GDP, even though the effect of gross fixed capital formation is not 
significant. Trade openness is however found to negatively influence economic growth. Theoretically, most of the pooled OLS results certify the apriori expectations, however; since the model does not accommodate the heterogeneity associated with the individual cross-sections, these results cannot be used for policy formulation.

Table-7. Pooled OLS Results.

\begin{tabular}{l|c|c|c|c}
\hline Variables & Coefficient & Std. Error & t-Statistic & Prob. \\
\hline Constant & 4.974968 & 0.335272 & 14.83861 & 0.0000 \\
\hline NBTOT & -0.000134 & 0.000793 & -0.169252 & 0.8658 \\
\hline GFCF & 0.003117 & 0.002184 & 1.427330 & 0.1555 \\
\hline LFT & 1.198399 & 0.060505 & 19.80652 & 0.0000 \\
\hline FDI & 0.311343 & 0.037975 & 8.198546 & 0.0000 \\
\hline TOPEN & -0.458218 & 0.043779 & -10.46654 & 0.0000 \\
\hline $\mathrm{R}^{2}$ & 0.865834 & & & \\
\hline F-Stat. & 201.3470 & & & \\
\hline Prob.(F-statistic) & 0.000000 & & & \\
\hline DW & 0.265694 & & & \\
\hline
\end{tabular}

Under the cross-section random effect results in Table 8 below, net barter terms of trade positively and significantly impact on GDP. This result is a complete departure from the result of the pooled OLS result. The implication of the result is that favourable terms of trade lead to improvement in the economic growth of a country. Thus, as the SSA natural resource-rich countries export their abundant natural resources and other commodities, their terms of trade improves which leads to improvement in their GDP. This result finds support in the finding by Mputu (2016). Finding also indicates that Gross fixed capital formation is significant and negatively influences GDP. The pooled OLS result for gross fixed capital formation shows that it does not have significant impact on GDP. The negative link between gross fixed capital formation and GDP finds support in a separate study by Nzeh (2020) for Nigeria which is one of the biggest economies in the group. One plausible reason why gross fixed capital formation influences GDP negatively could be owing to the fact that the countries comprising this group are less industrialized such that the capacity utilization of these fixed inputs is negligible. We found labour force total to positively influence GDP, but FDI does not have a significant effect on GDP even though the link is positive. The result of labour force finds conformity in Mputu (2016) and Ayadi (2017) and it shows the importance of labour productivity on economic growth. We guess that the non-significance of FDI on GDP could be due to the fact that these countries are less developed industrially as they rely mainly in the export of primary products. Also, as noted by Ayadi (2017) the hostile business environment which deters the inflow of investment could be the reason. Trade openness is found to have a negative impact on GDP and this finds support in Mputu (2016) and Ayadi (2017). As observed by Mputu (2016) resource curse hypothesis can be validated by this result as the countries hardly diversify their economies but only rely on export of abundant natural resources.

Under the period fixed effect result in Table 8, we find net barter terms of trade to negatively impact on GDP even though this impact is not significant. This result is similar to the result of pooled OLS, except that the size of the coefficient differs. The result shows the effect of period of time on the link between terms of trade and GDP. It is a common knowledge that primary export products which mainly account for the export of the countries in our sample usually experience volatility from time to time. It is the exogenous shocks in the price of these commodities that usually leads to the unfavourable terms of trade. We find gross fixed capital formation to insignificantly impact on GDP which is in line with the pooled OLS result. Results for labour force and FDI follow theoretical expectation as they impact positively on GDP. Also, result of trade openness is in conformity with findings by Ayadi (2017) and Mputu (2016) as it negatively impacts on GDP. What is perhaps revealing in the results is that the results for gross fixed capital formation and net terms of trade in both period fixed effects and pooled OLS are similar except that only the size of the coefficients of their parameter estimates differs. We found that the coefficients of the parameter estimates under the pooled OLS are higher than that of the period fixed effects.

Table-8. Results of Cross-section and Fixed Effects: GDP as the Dependent Variable

\begin{tabular}{|c|c|c|c|c|}
\hline \multicolumn{4}{|c|}{ Cross-Section Random Effect Results } & \multirow[b]{2}{*}{ Prob. } \\
\hline Variables & Coefficient & Std. Error & t-Statistic & \\
\hline Constant & 0.468267 & 0.667024 & 0.702025 & 0.4837 \\
\hline NBTOT & 0.000467 & 0.000196 & 2.381779 & 0.0184 \\
\hline GFCF & -0.001113 & 0.000658 & -1.691667 & 0.0927 \\
\hline LFT & 1.487516 & 0.127710 & 11.64762 & 0.0000 \\
\hline FDI & 0.002909 & 0.009883 & 0.294384 & 0.7689 \\
\hline TOPEN & -0.011371 & 0.029759 & -0.382102 & 0.7029 \\
\hline $\mathrm{R}^{2}$ & 0.848083 & & & \\
\hline F-Stat. & 174.1756 & & & \\
\hline Prob(F-statistic) & 0.000000 & & & \\
\hline $\mathrm{DW}^{2}$ & 0.157922 & & & \\
\hline \multicolumn{4}{|c|}{ Period Fixed Effect Results } & \\
\hline Variables & Coefficient & Std. Error & t-Statistic & Prob. \\
\hline Constant & 5.116940 & 0.444825 & 11.50327 & 0.0000 \\
\hline NBTOT & -0.000197 & 0.001023 & -0.192922 & 0.8473 \\
\hline GFCF & 0.002374 & 0.002548 & 0.931740 & 0.3532 \\
\hline LFT & 1.193007 & 0.100098 & 11.91842 & 0.0000 \\
\hline FDI & 0.329744 & 0.051529 & 6.399170 & 0.0000 \\
\hline TOPEN & -0.478658 & 0.061924 & -7.729717 & 0.0000 \\
\hline $\mathrm{R}^{2}$ & 0.878609 & & & \\
\hline F-Stat. & 27.03548 & & & \\
\hline Prob.(F-statistic) & 0.000000 & & & \\
\hline $\mathrm{DW}^{2}$ & 0.291087 & & & \\
\hline
\end{tabular}




\section{Conclusion and Recommendations}

In this study, we investigated the nexus between terms of trade and economic growth in sub-Saharan African natural resource-rich countries over a period of 1990-2019. We employed random and fixed effects panel models in the study along with pooled OLS which we used for the sake of comparison. Findings of our results indicate that a long run relationship exists between GDP and the explanatory variables used in the study. We also noted that the models used in the study do not exhibit similar results. For instance, while cross-section random effect indicates that net barter terms of trade positively impact on GDP, result of period fixed effect and pooled OLS show that net barter terms of trade negatively impacts on GDP even though it is not significant. Also, gross fixed capital formation is positively linked to GDP both under the pooled OLS and period fixed effect even though the result is not significant. Results of our study also show that in all the models, labour force total and FDI have positive link with GDP while trade openness negatively influences GDP. The positive impact of net barter terms of trade on GDP under the cross-section random effect is in tune with the export-led growth hypothesis, while the negative link between net barter terms of trade and GDP under the period fixed effects shows the existence of resourcecurse and Dutch disease hypotheses. The implication of the period fixed effects is that period volatility in the export price of SSA countries usually deteriorates their terms of trade. The period fixed effects result that shows a negative link between terms of trade and GDP finds support in the result of the link between trade openness and GDP which indicates negative link in all the models.

With respect to our findings, we recommend that the SSA resource-rich countries should diversify their economies away from the traditional natural resources base. This will assist these countries in effectively utilizing their fixed capital to enhance productivity. Human capital has been found to impact positively on GDP as evidence of our study has supported this with labour force total found to positively impact on GDP. On grounds of this, we recommend that efforts should be geared towards improving the labour force through sound education and training. Foreign direct investment has been found not to contribute to growth; we advise that conducive environment necessary for attracting foreign investment should be put in place. This requires institutional upgrading to remove all bottlenecks that hamper FDI inflows. In another dimension, we recommend a gradual migration from the production and export of consumer products to capital goods which are more competitive in the international market. This will help in improving the terms of trade of these countries and thus reduces the impact of exogenous shocks in the prices of the export of primary products. In terms of modeling the link between GDP and terms of trade in these countries, both period and cross-section fixed and random effects should be explored in order to get better results.

\section{References}

Ayadi, F. S. (2017). Resource endowment and economic growth in selected African countries. Journal of Management and Social Sciences, 6(2), 284-302.

Barro, R. J., \& Sala-i-Martin, X. (1995). Technological diffusion, convergence, and growth. National Bureau of Economic Research Working Paper 5151.

Blavasciunaite, D., Garsviene, L., \& Matuzeviciute, K. (2020). Trade balance effects on economic growth: Evidence from European Union countries. Economies, 8(3), 1-15. Available at: https://doi.org/10.3390/economies8030054.

Bruno, M., \& Sachs, J. D. (1985). Economics of worldwide stagflation. Cambridge, Massachusetts: Harvard University Press.

Carmignani, F., \& Chowdhury, A. (2007). The role of primary commodities in economic development: Sub-Sahara Africa versus the rest of world. United Nations Economic Commission for Europe, Discussion Paper Series, No. 2007.7.

Dabas, C., \& Delbianco, F. (2019). Exports, terms of trade and economic growth: Evidence from countries with different level of openness. Journal of Reviews on Global Economics, 8, 327-336. Available at: https://doi.org/10.6000/1929-7092.2019.08.28.

Easterly, W., Kremer, M., Pritchett, L., \& Summers, L. H. (1993). Good policy or good luck? Journal of Monetary Economics, 32(3), 459-483.

Fatima, N. (2010). Analyzing the terms of trade effect for Pakistan. Pakistan Institute of Development Working Paper No. 59.

Fischer, S. (1993). The role of macroeconomic factors in growth. Journal of Monetary Economics, 32(3), 485-512. Available at: https://doi.org/10.1016/0304-3932(93)90027-d.

Jawaid, S. T., \& Waheed, A. (2011). Effects of terms of trade and its volatility on economic growth: A cross country empirical investigation. Transition Studies Review, 18(2), 217-229. Available at: https://doi.org/10.1007/s11300-011-0201-7.

Jawaid., S. T., \& Raza, S. A. (2012). Effects of terms of trade and its volatility on economic growth in India. MPRA Paper No. 38998.

Jawaid.., S. T., Waheed, A., \& Siddiqui, A. H. (2020). Terms of trade and economic growth in developing country: Evidence from bilateral and commodity level analysis. Journal of Chinese Economic and Foreign Trade Studies, 13(1), 1-19. Available at: https://doi.org/10.1108/jcefts-07-2019-0035.

Jebran, K., Iqbal, A., Bhat, K.-U., \& Ali, A. (2018). Effect of terms of trade on economic growth of China. Emerging Economy Studies, 4(2), 157168. Available at: https://doi.org/10.1177/2394901518795068.

Mendoza, E. G. (1997). Terms-of-trade uncertainty and economic growth. Journal of Development Economics, 54(2), 323-356. Available at: https://doi.org/10.1016/s0304-3878(97)00046-1.

Mputu, C. L. (2016). Terms of trade openness and economic growth in sub-Saharan Africa., An M.SC Thesis Submitted to the Department of Economics, St. Cloud State University.

Nzeh, I. C. (2020). Public debt and economic growth in Nigeria: Investigating the optimal threshold level. Asian Development Policy Reviere, 8(2), 112-127. Available at: https://doi.org/10.18488/journal.107.2020.82.112.127.

Sachs, J. D., \& Warner, A. M. (2001). The curse of natural resources. European Economic Review, 45(4-6), 827-838.

Thirlwall, A. P. (1979). The balance of payments constraint as an explanation of international growth rate differences. BNL Quarterly Review, 32(128), 45-53. 